\title{
The Third Wave of the COVID-I9 in Afghanistan: An Update on Challenges and Recommendations
}

\section{Arash Nemat \\ Abdullah Asady (D)}

Department of Microbiology, Kabul University of Medical Sciences, Kabul, Afghanistan
Correspondence: Arash Nemat Department of Microbiology, Kabul University of Medical Sciences, Kabul, I00I, Afghanistan

Tel +9370 67I 7987

Email dr.arashnemat@yahoo.com

\begin{abstract}
The COVID-19 has spread to almost all countries since its emergence from Wuhan, China. Afghanistan has entered the third wave of the COVID-19 pandemic in May 2021. The county is bracing the third wave at a time when challenges like continuous conflict, illiteracy, poverty, inadequate healthcare personnel and service coverage, inadequate testing capacity, shortage of laboratory kits and reagents, lower public awareness and lower public trust on the government have brought it to its knees. All stakeholders including government, healthcare workers, civil societies, the public and the international community should combine their efforts to combat such a devastating situation. Although the inception of vaccination program against COVID-19 seems relieving, but it may take several months until a significant proportion of the people get vaccinated to reach the herd immunity. Thus, non-pharmaceutical intervention should be followed strictly. Moreover, awareness campaigns should also be continued to educate people and keep them supportive of the government plans and policies. Otherwise, the current wave may cause deadly consequences in such a complex situation.
\end{abstract}

Keywords: COVID-19, Afghanistan, pandemic, third wave

\section{Commentary}

The Corona Virus disease-2019 (COVID-19) caused by Severe Acute Respiratory Syndrome Coronavirus-2 first appeared in Wuhan, China. ${ }^{1}$ Soon after emergence, it was announced as a global pandemic by the World Health Organization (WHO) and in a few months it spread to almost every corner of the world. ${ }^{2}$ Until May 31, 2021, there have been $169,597,415$ confirmed cases of the COVID-19, including 3,530,582 deaths worldwide. $^{3}$

In Afghanistan, the first case was imported from Qum, Iran in March, 2020 and since then the disease has spread rapidly throughout the country. There have been a total of 69,130 confirmed cases and 2881 deaths due to COVID-19 as of May 28, 2021 according to official reports. ${ }^{4}$ However, these figures do not seem to correspond to the actual picture of the infection in the country. The Ministry of Public Health (MoPH) Afghanistan conducted a survey during the first wave of COVID-19 to investigate the spread of the infection and estimated that around 10 million people might have been infected by the COVID-19 in the country. ${ }^{5}$ This indicates that the official reports are lower than the actual infection rates. On May 3, 2021, MoPH announced the beginning of the third wave of COVID-19 in the country, ${ }^{6}$ and it was predicted that the infection will reach its peak during 10 subsequent days. ${ }^{7}$ On May 27, 2021, MoPH reported 977 new COVID-19 cases in the last 24 hours which was the highest number of reported daily cases until then. ${ }^{8}$ 
Afghanistan has an estimated population of 31.6 million. Almost two-thirds of people over the age of 15 are illiterate or poorly educated. ${ }^{9}$ There are about 9.4 skilled healthcare workers and 1.9 physicians per 10,000 population. They are distributed unevenly throughout the country. ${ }^{10}$ The country has been struggling with issues such as terrorism, criminal activities, narcotics production and trafficking and uncontrolled borders for decades. ${ }^{11}$

Higher rate of illiteracy, poor economic situation and insufficient testing capacity are considered as big challenges during the pandemic. ${ }^{12}$ Furthermore, lower public awareness, lower capability of healthcare system for timely receipt and treatment of patients and lower public trust on the healthcare sector have caused most patients to seek home treatment rather than referring to healthcare facilities. ${ }^{13}$

On the other hand, the normal flow of people's lives does not seem to show any changes. Markets, hotels, mosques, schools and universities are all overcrowded without following infection prevention protocols, such as using masks, avoiding crowded places, observing physical distance and following hygiene practices particularly within public communities and political events. ${ }^{14}$ This will likely cause a catastrophe in the not-too-distant future in the country, if not controlled immediately.

Moreover, the lack of healthcare personnel for gathering the sample of suspected individuals and the shortage of kits for laboratory diagnostic tests are other big challenges in many districts of Afghanistan during the early days of the third wave. Likewise, extreme poverty in some remote provinces has a destructive effect on the provision and coverage of healthcare services for general public. ${ }^{10}$ Meanwhile, many people who received the first dose of the COVID-19 vaccine in Afghanistan, have not received the next dose due to shortage of vaccine supply. ${ }^{15}$

To control such a large-scale crisis, the government, civil societies, healthcare workers and other stakeholders including the international community should streamline the infection prevention/control strategies using the experiences of the previous waves to reduce the ongoing threat. Despite the inception of vaccine initiative, it might take several months to vaccinate a significant portion of the population required to reach the herd immunity. Thus, the role of non-pharmaceutical interventions cannot be ignored. In fact, we still need to rely on the infection prevention protocols largely in order to reduce the infection transmission rate and corresponding damages. In addition, public awareness campaigns should be continued to keep people supportive of the government policies.

\section{Abbreviations}

COVID-19, coronavirus disease 2019; MoPH, The Ministry of Public Health.

\section{Disclosure}

The authors report no conflicts of interest in this work.

\section{References}

1. Liu Y-C, Kuo R-L, Shih S-R. COVID-19: the first documented coronavirus pandemic in history. Biomed J. 2020;43(4):328-333. doi:10.1016/j.bj.2020.04.007

2. Zhu W, Chen CZ, Gorshkov K, Xu M, Lo DC, Zheng W. RNAdependent RNA polymerase as a target for COVID-19 drug discovery. SLAS Discovery. 2020;25(10):1141-1151.

3. World Health Organization (WHO). Weekly operational update on COVID-19; 2021. Available from: https://www.who.int/publications/ $\mathrm{m} /$ item/weekly-operational-update-on-covid-19-31-may-2021.

Accessed July 17, 2021.

4. World Health Organization (WHO). Afghanistan; 2021. Available from: https://covid19.who.int/region/emro/country/af. Accessed May 28, 2021.

5. Nemat A, Asady A, Raufi N, et al. A survey of the healthcare workers in Afghanistan during the COVID-19 pandemic. Am J Trop Med Hyg. 2020;104(2):537.

6. BAKHTAR News Agency. Afghanistan records 3rd wave of Coronavirus; 2021. Available from: https://bakhtarnews.af/afghani stan-records-3rd-wave-of-coronavirus/. Accessed May 28, 2021.

7. THE TIMES OF INDIA. Afghanistan may see third wave of Covid-19 peak in 10 days: health ministry; 2021. Available from: https://timesofindia.indiatimes.com/world/south-asia/afghanistan-may -see-third-wave-of-covid-19-peak-in-10-days-health-ministry/article show/82968270.cms. Accessed May 28, 2021.

8. Pajhwok Afghan News. Afghanistan registers 977 positive Covid-19 cases in past $24 \mathrm{hrs} ; 2021$. Available from: https://pajhwok.com/ 2021/05/28/afghanistan-registers-977-positive-covid-19-cases-in-past $-24 \mathrm{hrs} /$. Accessed May 29, 2021.

9. Qaderi S, Mousavi SH, Ahmadi A, et al. Transfusion-dependent beta thalassemia in Afghanistan: current evidence amid COVID-19 and future recommendations. Hematology. 2021;26(1):432-434. doi:10. 1080/16078454.2021.1938814

10. Shah J, Karimzadeh S, Al-Ahdal TMA, Mousavi SH, Zahid SU, Huy NT. COVID-19: the current situation in Afghanistan. Lancet Global Health. 2020;8(6):e771-e772. doi:10.1016/S2214-109X(20) 30124-8

11. Weinbaum MG. Afghanistan and the great powers in regional geopolitics, economics and security. In: The Great Power Competition Volume 1. Springer; 2021:413-430.

12. Lucero-Prisno DE, Ahmadi A, Essar MY, Lin X, Adebisi YA. Addressing COVID-19 in Afghanistan: what are the efforts and challenges? $J$ Glob Health. 2020;10(2):020341. doi:10.7189/ jogh.10.020341

13. BBC. Coronavirus overwhelms hospitals in war-ravaged Afghanistan; 2020. Available from: https://www.bbc.com/news/ world-asia-53198785. Accessed May 31, 2021.

14. TOLONEWS. Political leaders warn taliban against push for military win; 2021. Available from: https://tolonews.com/index.php/afghani stan-172453. Accessed May 28, 2021.

15. World Health Organization (WHO) Regional Office for the Eastern Mediterranean. COVID-19 vaccines shipped by COVAX arrive in Afghanistan; 2021. Available from: http://www.emro.who.int/afg/ afghanistan-news/covid-19-vaccines-shipped-by-covax-arrive-inafghanistan.html. Accessed May 28, 2021. 


\section{Publish your work in this journal}

The Journal of Multidisciplinary Healthcare is an international, peerreviewed open-access journal that aims to represent and publish research in healthcare areas delivered by practitioners of different disciplines. This includes studies and reviews conducted by multidisciplinary teams as well as research which evaluates the results or conduct of such teams or healthcare processes in general. The journal

covers a very wide range of areas and welcomes submissions from practitioners at all levels, from all over the world. The manuscript management system is completely online and includes a very quick and fair peer-review system. Visit http://www.dovepress.com/testimonials. php to read real quotes from published authors. 